LE-1, ENSIS LE-5, ENSIS LE-6 were used.

Based on the results of the control, it was concluded that for fermentation of the worts of aplles Spartan, it is advisable to use the ECS of the EC 1118, ENSIS LE-5 and ENSIS LE6 races. The fermentation temperature of the wort is $18-25^{\circ} \mathrm{C}$.

The dynamics of the volume fraction of ethyl alcohol $(y, \%)$ depends on the fermentation time $(x$, day) under the condition of an optimal fermentation process with a mass concentration of sugars of $266 \mathrm{~g} / \mathrm{dm}^{3}$ at the beginning of the process from Spartan apples can be described by the quadratic parabola equation: $y=-0.005 x^{2}+0.528 x+$ 2.619. Scope of use is from 1 to 76 days, with a tolerance of $1.4 \%$. On the 22nd day, the volume of ethyl alcohol in the wort should not be less than $13 \%$.

Under the condition of an optimal fermentation process with a mass concentration of sugars $300 \mathrm{~g} / \mathrm{dm}^{3}$ at the beginning of the process from Spartan apples can be described by the quadratic parabola equation: $y=-0.0112 x^{2}+0.8834 x+0.8776$. Scope of use is from 1 to 56 days, with a tolerance of 1.4\%. On the 17th day, the volume fraction of ethyl alcohol in the wort should be at least $13 \%$.

The created models can be used to compare the results of fermentation monitoring and critical evaluation of the process, and, if necessary, its timely regulation.

Key words: apple wort, fermentation process, optimization, yeast, unfortified wine materials.

DOI 10.31395/2415-8240-2019-95-1-55-65

\title{
EFFICACY OF FOLIAR APPLICATION OF MICROFERTILIZERS ON THE BIOCHEMICAL PARAMETERS OF POTATO TUBERS
}

\author{
R. O. MYALKOVSKY, Doctors of Agricultural Sciences \\ P. V. BEZVIKONNYI, Candidate of Agricultural Sciences \\ O. I. MULYARCHUK, Candidate of Agricultural Sciences \\ State Agrarian And Engineering University in Podilya \\ V. S. KRAVCHENKO, Candidate of Agricultural Sciences \\ Uman National University of Horticulture
}

Наведено результати позакореневого підживлення мікродобривами на біохімічні показники бульб картоплі в умовах Правобережного Лісостепу України. встановлено, що застосування у позакореневе піджсивлення мікродобрив Реаком, Кристалон особливий $і$ Розасоль призводило до підвищення вмісту сухої речовини, крохмалю та вітаміну С. Найвищим вмістом сухої речовини відзначались варіанти із внесенням мікродобрив 
Реаком нормою 4,50 кг/га, в середньому за три роки сорт Алладін - 24,55\% $i$ Дар - 24,34\%. Найвищий вміст крохмалю також відмічено від оброблення рослин Реакомом нормою мікродобрив 4,50 кг/га сорту Алладін - 21,7 \%, copmy Дар - 17,5 \%. Застосування мікродобрив для позакореневого підживлення рослин картоплі підвищувало вміст вітаміну С в бульбах.

Ключові слова: картопля, сорт, мікродобрива, позакореневе підживлення, урожай, суха речовина, крохмаль, вітамін $C$.

Introduction. Potato (Solanum tuberosum L.) -- perennial herb of the family of Solancers (Solanace L.), which brings together up to 150 wild and cultivated potato species. Potatoes are quite demanding about the nutrients in the soil [1].

It's a well known fact that in increasing potato yields the most important factor is to provide the plants with nutrients. However, at the present situation, the production of mineral and organic fertilizers as a source of nutrients for plants has significantly decreased. Modern technologies of cultivation of crops involve introduction of various mineral and organic fertilizers in rather high standards. It can negatively affect all components of agrocenosis, increase pollution of products and environment by agrochemicals and their metabolites. Such technologies are particularly unacceptable for growing agricultural products in areas affected by environmental pollution caused by the release of various harmful substances into the atmosphere. Therefore, one of the ways out of this situation is to use new means of chemistry (chelating forms of microfertilizers), which will reduce the risk of product contamination.

Analysis of recent research and publications. With modern technology of growing vegetables, including potatoes, it is impossible to obtain stable high quality crops without the use of environmentally friendly, balanced micro fertilizers, which would provide plants with all the necessary biogenic elements during the growing season [2].

On the optimal mineral background, potatoes respond well to foliar feeding with a complex of compounds of nitrogen, phosphorus, potassium, magnesium and trace elements - $\mathrm{Mn}, \mathrm{B}, \mathrm{Cu}, \mathrm{Zn}$, which in an optimal ratio and in an easily accessible form quickly enter the cells of plants through the leaf surface. Such nutrition, regardless of the soil supply with biogenic elements, increase the yield by $10-15 \%$ and improve the quality of the tubers (starch content, dry matter content, tuber stickiness, nitrate content decrease, taste and product quality are improved) $[3,4]$. 
Maximum realization of genetic potential is closely linked to providing plants with all the necessary factors: balanced mineral nutrition and soil moisture, optimum temperature, solar insolation and protection during the growing season against biological objects and stress. In certain stressful situations, in order to reduce the negative impact of the stress factor, microfertilizers and fertilizers containing biostimulants that are introduced out of root are used [5, 6].

Fertilizers for foliar fertilization should be widely used, in conjunction with plant protection products as an effective and insignificant way to increase the yield of tubers and improve their quality [7].

The yield of potatoes is positively affected by trace elements. The formation of $10 \mathrm{t}$ of potatoes requires $25 \mathrm{~g}$ of boron, $20 \mathrm{~g}$ of copper, $70 \mathrm{~g}$ of manganese, $1 \mathrm{~g}$ of molybdenum, $65 \mathrm{~g}$ of zinc [8].

During the processing of tubers or plants during the growing season, trace elements of copper (10-20 g / t; 200-300 g / ha), zinc sulfate (10-20 g / t; 150-200 $\mathrm{g} / \mathrm{ha})$, ammonium molybdenum (10 -20 g / t; $200 \mathrm{~g} / \mathrm{ha})$, boric acid (40-60 g / t), manganese sulfate (40-60 g / t; $200 \mathrm{~g} / \mathrm{ha}$ ). But along with classic salts, to optimize the mineral nutrition of crops it is proposed to apply chelated forms of microfertilizers: Quantum, Intermag, Vuxal, Reakom, Crystalone special, Rozasol, Nutrivant, ADOB, Ecologist and others.

According to the Podil Research Station of the Ternopil Institute AIP(agro industrial production) was installed that when using superbiofertilizers potato yields increase from 31 to $78 \mathrm{~kg} / \mathrm{ha}$, corn silo from 9 to $76 \mathrm{~kg} / \mathrm{ha}$, sugar beets from 56 to $111 \mathrm{~kg} /$ ha [10].

Analysis of the literature on the topic chosen, we conclude that the fertilizer with micronutrients chelate play an important role in increased productivity and quality of potatoes.

Research methodology. The studies were conducted at the research field of the Podillya Training and Production Center of Podilsky State Agrarian and Technical University during 2015-2017.

Soil of the experimental field - black soil typical leached, little humus, medium loam on forest loam. The humus content (according to Tyurin) in the soil layer $0-3 \mathrm{~cm}$ is $3.6-4.2 \%$. The content of easily hydrolyzable nitrogen compounds (Cornfield) is $98-139 \mathrm{mg} / \mathrm{kg}$ (high), mobile phosphorus (Chirikov) $143-185 \mathrm{mg} /$ $\mathrm{kg}$ (high) and potassium exchange (Chirikov) - 153-185 mg / $\mathrm{kg}$ of soil (high). The amount of absorbed bases ranges from 158-209 mg eq / kg. Hydrolytic acidity is $17-22 \mathrm{mg}$ eq / $\mathrm{kg}$, the degree of saturation of the basics $-90 \%$.

Evaluation of the effectiveness of the use of microfertilizers for foliar feeding of potato plants on the yield and quality of tubers (2015-2017). 
The foliar feeding of the plants was carried out in the budding phase flowering (intensive growth). For research, we used microfertilizers " Reakom ", " Crystalone special", " Rozasol ".

Reakom - boron content of $10 \mathrm{~g} / 1+$ microfertilizers (in chelated form of OEDF acid + citric acid; Mo - 5,6, Mn - 5,0, Cu - 4,5, Zn - 4,0, Co - $1.7 \mathrm{u} / \mathrm{k}, \mathrm{pH}$ 8,0, density - 1,136 g / cm3; " Crystalone Special" - $\mathrm{N}_{18} \mathrm{P}_{18} \mathrm{~K}_{18}+$ microfertilizers (in chelated form EDTA, DTR) B - 0,025\%; Cu - 0,01\%; Mn - 0,04; Mo - 0,004; $\mathrm{Zn}-0,0025 \%$. Rosazol $-\mathrm{N}_{18} \mathrm{P}_{18} \mathrm{~K}_{18}+$ microfertilizers (in chelated EDTA form) B $125 \mathrm{mg} / \mathrm{kg}$; Mn - 400; Cu - 94; Fe - 325; Zn - 287 mg / kg.

The experiment used medium-late varieties of Alladin and Dar, which are listed in the State Register of Plant Varieties of Ukraine and not studied in the soil and climatic conditions of the zone.

Phenological observations, biometric and physiological-biochemical studies were performed according to the methods by GL. Bondarenko, K.I. Yakovenko., V.F. Mosaichenko [11, 12].

Research results. The use of microfertilizers (Reakom, Crystalone special and Rozasol) in foliar fertilization in the Alladin and Dar varieties contributed to the accumulation of dry matter content in the tubers compared to the control variant of the studies (Table 1).

The results of the analysis of the tubers show that the dry matter content of Reakom nutrition varied within the Alladin variety from $23.52 \%$ to $24.99 \%$ on the variant with the introduction of micro fertilizers with the rate of $4.50 \mathrm{~kg} / \mathrm{ha}$. Grades Dar indicators were respectively $-23,18 \%$ and $24,78 \%$.

The variants with the introduction of Reakom micro fertilizers with the rate of $4.50 \mathrm{~kg} / \mathrm{ha}$ on average over the three years of the Alladin variety $-24.55 \%$, Dar $-24.34 \%$ were the highest. $4.00 \mathrm{~kg} /$ ha and $5.00 \mathrm{~kg} /$ ha with the dry matter content of Alladin grade are $24.28 \%$ and $24.35 \%$, Dar $-24.04 \%$ and $23.99 \%$ respectively. The intermediate place is occupied by norms $4.00 \mathrm{~kg} / \mathrm{ha}$ and $5.00 \mathrm{~kg}$ / ha with the content of the dry matter of the Alladin variety are $24.28 \%$ and $24.35 \%$, Dar $-24.04 \%$ and $23.99 \%$ respectively.

The analysis of the dry matter content in the tubers with the treatment of plants by Crystalone, especially in the feeding of the highest indices, the rate of introduction stands out $2.50 \mathrm{~kg} / \mathrm{ha}$, in the Alladin variety - 24.14\%, Dar $24.18 \%$, in comparison with the control variant they were higher by $0.71 \%$ and $0.84 \%$, respectively. The similar indicators with the application of foliar feeding of Rozasol microfertilizers. To estimate the dry matter content of the tubers, the highest content was characterized by the variant with the application rate of 2.50 $\mathrm{kg} /$ ha of Alladin variety $-24.06 \%$, Dar $-24.06 \%$. 


\section{Dry matter content in potato tubers depending on foliar fertilization by micro fertilizers, \%}

\begin{tabular}{|c|c|c|c|c|c|c|c|c|c|}
\hline \multirow{4}{*}{ 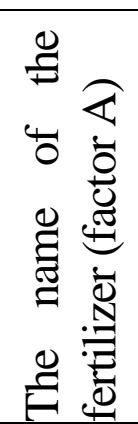 } & \multirow{4}{*}{$\begin{array}{l}\text { Application rate of } \\
\text { microfertilizers kg / ha } \\
\text { (factor B) }\end{array}$} & \multicolumn{8}{|c|}{ Variety (factor C) } \\
\hline & & \multicolumn{4}{|c|}{ Alladin } & \multicolumn{4}{|c|}{ Dar } \\
\hline & & \multicolumn{3}{|c|}{ Year } & \multirow[b]{2}{*}{ 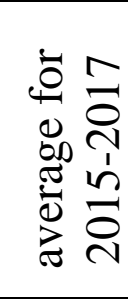 } & \multicolumn{3}{|c|}{ Year } & \multirow[b]{2}{*}{ 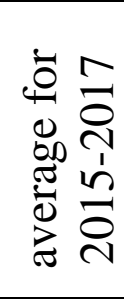 } \\
\hline & & $\frac{n}{\delta}$ & $\frac{0}{\stackrel{0}{\sigma}}$ & $\overline{\widetilde{d}}$ & & $\frac{n}{\tilde{d}}$ & $\frac{0}{\stackrel{0}{~}}$ & $\overline{\bar{d}}$ & \\
\hline \multicolumn{2}{|c|}{ Without plant treatment $(\mathrm{c}) *$} & 23,39 & 24,01 & 24,39 & 23,93 & 23,54 & 23,97 & 24,18 & 23,90 \\
\hline \multirow{4}{*}{ 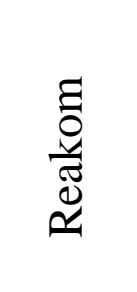 } & 4,00 & 23,78 & 24,12 & 24,93 & 24,28 & 23,93 & 23,99 & 24,21 & 24,04 \\
\hline & 4,50 & 23,88 & 24,78 & 24,99 & 24,55 & 24,11 & 24,12 & 24,78 & 24,34 \\
\hline & 5,00 & 23,73 & 24,55 & 24,77 & 24,35 & 23,74 & 23,83 & 24,40 & 23,99 \\
\hline & 5,50 & 23,52 & 24,17 & 24,90 & 24,20 & 23,34 & 23,18 & 24,00 & 23,51 \\
\hline \multicolumn{2}{|c|}{ Without plant treatment $(\mathrm{c}) *$} & 22,96 & 23,00 & 24,32 & 23,43 & 23,15 & 23,01 & 23,87 & 23,34 \\
\hline \multirow{4}{*}{ 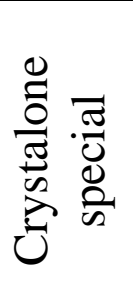 } & 1,50 & 22,97 & 23,27 & 24,73 & 23,66 & 23,74 & 23,56 & 23,96 & 23,75 \\
\hline & 2,00 & 23,00 & 23,31 & 24,74 & 23,68 & 23,81 & 23,91 & 24,11 & 23,94 \\
\hline & 2,50 & 23,76 & 23,88 & 24,78 & 24,14 & 24,10 & 24,01 & 24,44 & 24,18 \\
\hline & 3,00 & 23,01 & 23,73 & 24,41 & 23,72 & 23,74 & 23,91 & 24,06 & 23,90 \\
\hline \multicolumn{2}{|c|}{ Without plant treatment $(\mathrm{c}) *$} & 23,41 & 23,77 & 24,01 & 23,73 & 23,47 & 23,9 & 23,99 & 23,79 \\
\hline \multirow{4}{*}{ 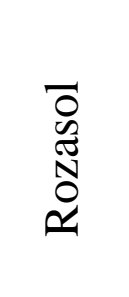 } & 2,00 & 23,66 & 23,54 & 23,84 & 23,68 & 23,51 & 23,66 & 23,61 & 23,59 \\
\hline & 2,50 & 24,01 & 24,01 & 24,15 & 24,06 & 23,99 & 23,83 & 24,37 & 24,06 \\
\hline & 3,00 & 23,67 & 23,55 & 24,66 & 23,96 & 23,81 & 23,54 & 23,52 & 23,62 \\
\hline & 3,50 & 23,70 & 23,46 & 23,52 & 23,56 & 23,36 & 23,36 & 23,49 & 23,40 \\
\hline
\end{tabular}

Note: $*(c)$ - control

2015: $L S D_{05(A B C)}=1,01 ; L S D_{05(A)}=0,32 ; L S D_{05(B)}=0,41 ; L S D_{05(C)}=0,26 ; L S D_{05(A B)}=0,71 ; L S D_{05(A C)}$ $=0,45 ; L S D_{05(B C)}=0,58$.

2016: $L S D_{05(A B C)}=098 ; L S D_{05(A)}=0,28 ; L S D_{05(B)}=0,36 ; L S D_{05(C)}=0,23 ; L S D D_{05(A B)}=0,62$; $L S D_{05(A C)}=0,39 ; L S D_{05(B C)}=0,51$.

2017: $L S D_{05(A B C)}=0,95 ; L S D_{05(A)}=0,30 ; L S D_{05(B)}=0,39 ; L S D_{05(C)}=0,25 ; L S D_{05(A B)}=0,67 ; L S D_{05(A C)}$ $=0,42 ; L S D_{05(B C)}=0,55$.

The lowest dry matter content was characterized by the variants with the introduction of Reakom and Crystalone special and Rozasol with the rate of 5.50 $\mathrm{kg} / \mathrm{ha}, 1.50 \mathrm{~kg} / \mathrm{ha}$ and $3.50 \mathrm{~kg} / \mathrm{ha}$, in both studied varieties.

Important in the application of microfertilizers for the foliar fertilization of potato plants is the indicator of the starch content in the tubers, which to some extent is a genetically fixed variety trait, however, this indicator may vary depending on the drugs used (Table 2). 


\section{Starch content in potato tubers depending on foliar fertilization by micro}

fertilizers, $\%$

\begin{tabular}{|c|c|c|c|c|c|c|c|c|c|}
\hline \multirow{4}{*}{ 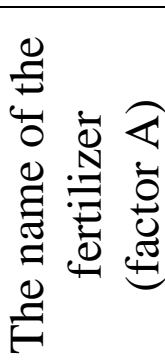 } & \multirow{4}{*}{$\begin{array}{l}\text { Application rate of } \\
\text { microfertilizers } \mathrm{kg} / \mathrm{ha} \\
\text { (factor } \mathrm{B})\end{array}$} & \multicolumn{8}{|c|}{ Variety (factor C) } \\
\hline & & \multicolumn{4}{|c|}{ Alladin } & \multicolumn{4}{|c|}{ Dar } \\
\hline & & \multicolumn{3}{|c|}{ Year } & \multirow[b]{2}{*}{ 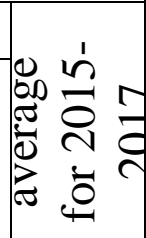 } & \multicolumn{3}{|c|}{ Year } & \multirow[b]{2}{*}{ 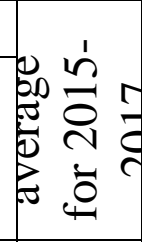 } \\
\hline & & $\frac{n}{\delta}$ & 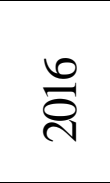 & 호 & & $\frac{n}{i}$ & 음 & 호 & \\
\hline \multicolumn{2}{|c|}{ Without plant treatment $(\mathrm{c}) *$} & 20,3 & 20,1 & 20,4 & 20,3 & 16,3 & 16,1 & 16,6 & 16,3 \\
\hline \multirow{4}{*}{ 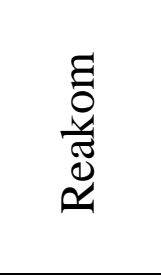 } & 4,00 & 20,9 & 20,5 & 20,9 & 20,8 & 16,8 & 16,7 & 16,9 & 16,8 \\
\hline & 4,50 & 21,8 & 21,6 & 21,8 & 21,7 & 17,4 & 17,3 & 17,8 & 17,5 \\
\hline & 5,00 & 20,3 & 21 & 20,9 & 20,7 & 16,8 & 16,5 & 17,1 & 16,8 \\
\hline & 5,50 & 20,7 & 20,8 & 20,6 & 20,7 & 17 & 16,6 & 16,8 & 16,8 \\
\hline \multicolumn{2}{|c|}{ Without plant treatment $(\mathrm{c}) *$} & 20,4 & 20,3 & 20,8 & 20,5 & 16,4 & 16,3 & 16,9 & 16,5 \\
\hline \multirow{4}{*}{ 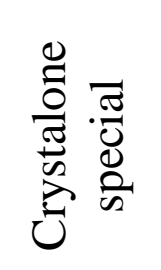 } & 1,50 & 20,5 & 20,6 & 20,9 & 20,7 & 16,7 & 16,6 & 17,2 & 16,8 \\
\hline & 2,00 & 20,7 & 20,5 & 20,9 & 20,7 & 16,9 & 16,8 & 17,1 & 16,9 \\
\hline & 2,50 & 21,9 & 21,8 & 21,9 & 21,9 & 17,8 & 17,9 & 17,8 & 17,8 \\
\hline & 3,00 & 20,8 & 20,6 & 20,8 & 20,7 & 17,6 & 17,6 & 17,7 & 17,6 \\
\hline \multicolumn{2}{|c|}{ Without plant treatment $(\mathrm{c}) *$} & 20,5 & 20,6 & 20,9 & 20,7 & 16,8 & 16,1 & 16,3 & 16,4 \\
\hline \multirow{4}{*}{ 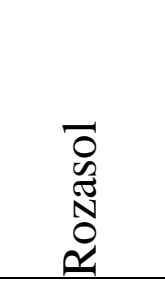 } & 2,00 & 20,6 & 20,7 & 20,8 & 20,7 & 16,8 & 16,4 & 16,6 & 16,6 \\
\hline & 2,50 & 21,7 & 21,5 & 21,5 & 21,6 & 17 & 16,5 & 16,9 & 16,8 \\
\hline & 3,00 & 20,8 & 20,3 & 20,9 & 20,7 & 16,8 & 16,7 & 16,8 & 16,8 \\
\hline & 3,50 & 20,8 & 20,7 & 20,5 & 20,7 & 16,7 & 16,3 & 16,6 & 16,5 \\
\hline
\end{tabular}

The highest starch content was characterized by the foliar application of Reakom microfertilizers. Thus, the average Alladin varieties in the years of research the highest this indicator was observed from the treatment of plants with the rate of micro fertilizers $4.50 \mathrm{~kg} / \mathrm{ha}$, where the starch content was $21.7 \%$, whereas in the control variant only $20.3 \%$.

Similar indicators and grades of Dar, (average for three years) $-17,5 \%$, on control $-16,3 \%$. The Crystalone microfertilizers are special and Rozasol as a whole also increases the starch content of the potato tubers. The highest rates of Alladin and Dar varieties were from the norm of Crystalone special - $2.50 \mathrm{~kg} / \mathrm{ha}$, Rozasol $-2.50 \mathrm{~kg} / \mathrm{ha}$. According to this norm, the content of starch (Crystalone special) increased by $21.9 \%$, (Rozasol) by $21.6 \%$ of Alladin honeycomb and $17.8 \%$ and $16.8 \%$ of Dar variety.

The use of micro and macro fertilizers helps to increase the yield, its 
stability over the years and to increase starch collection. Potato starch is a highquality feature and less variable in potato cultivation. The highest efficiency of the investigated preparations was ensured by the use of Reac and Crystalone microfertilizers.

One of the important chemical indicators of the composition of potato tubers is the content of vitamin $\mathrm{C}$.

According to the results of experimental studies, it was found that the high content of vitamin $\mathrm{C}$ was characterized by the Alladin variety (Table 3 ).

Among the fertilizers in the foliar fertilization of potato plants stands out Reakom. Of the options $4.50 \mathrm{~kg} / \mathrm{ha}$ is the most effective. Vitamin C content in potatoes of Alladin and Dar potatoes, respectively, averages three years, $16.6 \mathrm{mg} /$ $100 \mathrm{~g}$ and $14.9 \mathrm{mg} / 100 \mathrm{~g}$ of crude weight. With the use of the Crystalone special and Rozasol the most effective rate was $2.50 \mathrm{~kg} / \mathrm{ha}$.

3. Vitamin $\mathrm{C}$ content in potato tubers depending on foliar feeding by microfertilizers, $\mathrm{mg} / \mathrm{100} \mathrm{g}$ wet weight

\begin{tabular}{|c|c|c|c|c|c|c|c|c|c|}
\hline \multirow{4}{*}{ 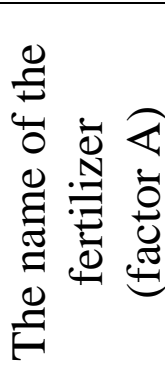 } & \multirow{4}{*}{$\begin{array}{c}\text { Application rate of } \\
\text { microfertilizers kg / ha } \\
\text { (factor B) }\end{array}$} & \multicolumn{8}{|c|}{ Variety (factor C) } \\
\hline & & \multicolumn{4}{|c|}{ Alladin } & \multicolumn{4}{|c|}{ Dar } \\
\hline & & \multicolumn{3}{|c|}{ Year } & \multirow{2}{*}{ 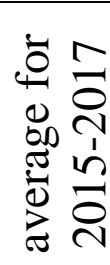 } & \multicolumn{3}{|c|}{ Year } & \multirow{2}{*}{ 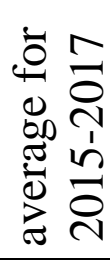 } \\
\hline & & $\frac{n}{i}$ & $\stackrel{0}{\stackrel{0}{\sigma}}$ & 공 & & $\frac{n}{\tilde{d}}$ & $\stackrel{0}{\stackrel{0}{\sigma}}$ & $\frac{\sqrt{\sigma}}{\mathrm{d}}$ & \\
\hline \multicolumn{2}{|c|}{ Without plant treatment $(\mathrm{c}) *$} & 15,9 & 15,0 & 15,8 & 15,6 & 14,1 & 14,0 & 14,3 & 14,1 \\
\hline \multirow{4}{*}{$\begin{array}{l}\tilde{0} \\
\frac{0}{\tilde{D}} \\
\simeq\end{array}$} & 4,00 & 16,1 & 15,8 & 15,9 & 15,9 & 14,4 & 14,2 & 14,6 & 14,4 \\
\hline & 4,50 & 16,3 & 16,7 & 16,9 & 16,6 & 14,9 & 14,8 & 15,0 & 14,9 \\
\hline & 5,00 & 16,7 & 16,3 & 16,0 & 16,3 & 14,7 & 14,5 & 14,6 & 14,6 \\
\hline & 5,50 & 16,4 & 16,0 & 16,5 & 16,3 & 14,8 & 14,3 & 14,8 & 14,6 \\
\hline \multicolumn{2}{|c|}{ Without plant treatment $(\mathrm{c}) *$} & 15,6 & 15,4 & 15,9 & 15,6 & 14,4 & 14,3 & 14,6 & 14,4 \\
\hline \multirow{4}{*}{ 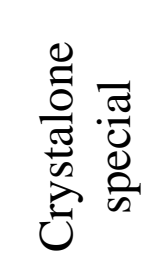 } & 1,50 & 15,9 & 15,5 & 15,8 & 15,7 & 14,6 & 14,4 & 14,8 & 14,6 \\
\hline & 2,00 & 15,9 & 15,6 & 15,9 & 15,8 & 14,9 & 14,7 & 14,9 & 14,8 \\
\hline & 2,50 & 16,4 & 16,0 & 16,3 & 16,2 & 15,2 & 15,0 & 15,4 & 15,2 \\
\hline & 3,00 & 15,3 & 15,7 & 15,9 & 15,6 & 14,9 & 14,7 & 14,9 & 14,8 \\
\hline \multicolumn{2}{|c|}{ Without plant treatment $(\mathrm{c}) *$} & 15,7 & 15,4 & 15,7 & 15,6 & 14,3 & 14,1 & 14,3 & 14,2 \\
\hline \multirow{4}{*}{ 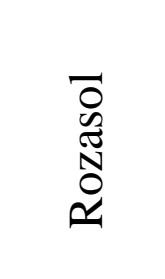 } & 2,00 & 15,8 & 15,7 & 15,9 & 15,8 & 14,4 & 14,4 & 14,5 & 14,4 \\
\hline & 2,50 & 16,4 & 16,0 & 16,2 & 16,2 & 15,0 & 14,8 & 15,2 & 15,0 \\
\hline & 3,00 & 15,9 & 15,7 & 15,8 & 15,8 & 14,7 & 14,7 & 14,8 & 14,7 \\
\hline & 3,50 & 15,6 & 15,4 & 15,8 & 15,6 & 14,6 & 14,8 & 14,8 & 14,7 \\
\hline
\end{tabular}


The highest levels of vitamin $\mathrm{C}$ in the Alladin variety were $16.2 \mathrm{mg} / 100 \mathrm{~g}$ and $16.2 \mathrm{mg} / 100 \mathrm{~g}$ of crude weight, the Dar variety $-15.2 \mathrm{mg} / 100 \mathrm{~g}$ and 15.0 $\mathrm{mg} / 100 \mathrm{~g}$, respectively. In general, the applied microfertilizers for foliar nutrition of potato plants exceeded the vitamin $\mathrm{C}$ control variant in terms of vitamin $\mathrm{C}$ content.

Conclusions. Therefore, based on the results of research, we can conclude that weather conditions are favorable for the cultivation of potato varieties, and the use of micronutrients in the foliar feeding of potato plants, especially Reacom and Crystalone especially contributes to the increase of dry matter, starch and vitamin C content in potato tubers.

Thus, further study and improvement should focus on in-depth study of foliar fertilization by microfertilizers, in particular, in the form of metal complexants on potato crops in combination with growth regulators and disclosure of their effect on the development and formation of plant productivity traits during ontogeny.

\section{Література}

1. Лихочвор В. В., Проць Р. Р. Картопля, топінамбур, батат та ін. Львів : Українські технології, 2002. $68 \mathrm{c.}$

2. Власенко Н. Е. Удобрение картофеля : монография. Москва: Агропромиздат, 1987. $219 \mathrm{c}$.

3. Власенко М., Вельямінова Л., Кононенко О., Кієнко 3. Оцінка господарсько - цінних і споживчих якостей нових сортів картоплі. Картопляр. 2002. № 2. С. 4-5.

4. М'ялковський Р. О. Біохімічні показники бульб картоплі за використання мікродобрив. Вісник ХНАУ. Серія «Рослинництво, селекція і насінництво, плодоовочівництво і зберігання». ХНАУ, 2018. Вип.1. С. 23-31.

5. Шпаар Д., Быкин А., Дрегер Д. Картофель. Мінськ: ЧУП «Орех», 2004. 465 c.

6. Аверкиева Е. Г. Картофель и его культура. Москва: Колос, 1988. 253 с.

7. Руденко Г. С., Ткачук І. А. Система удобрення картоплі. Київ : Урожай, 1980. 48 с.

8. Власенко Н. Ю. Удобрение картофеля. Москва: Агропромиздат, 1987. 261 c.

9. Кучко А. А., Мицько В.М. Фізіологічні основи формування врожаю і якості картоплі. Київ : Довіра, 1997. 126 с.

10. Шуль Д. Вивчення ефективності супербіодобрива Подільською дослідною станцією Тернопільського інституту АПВ. Тернопіль, 2001. 278 с. 
11. Бондаренко Г. Л., Яковенко К. І. Методика дослідної справи в овочівництві і баштанництві. Харків: Основа, 2001. 370 с.

12. Моисейченко В. Ф., Трифонова М. Ф., Завирюха А. Х. Основы научных исследований в агрономии. Москва: Колос, 1996. 336 с.

\section{References}

1. Lykhochvor V. V., Prots R. R. (2002) Potatoes, Jerusalem artichoke, yam, etc. Lviv. Ukrainian technologies, 2002. 68 p. (in Ukrainian).

2. Vlasenko N. Ye. (1987) Potato Fertilizer: Monograph. Moscow: Agropromizdat, 1987. 219 p. (in Russian).

3. Vlasenko M., Veliaminova L., Kononenko O., Kiienko Z. (2002) Assessment of economically valuable and consumer qualities of new potato varieties. The potato, 2002. no. 2, pp. 4-5. (in Ukrainian).

4. M'ialkovskyi R. O. (2018) Biochemical parameters of potato tubers for the use of microfertilizers. KhNAU Bulletin. Series "Crop, breeding and seed production, horticulture and storage", 2018. no. 1, pp. 23-31. (in Ukrainian).

5. Shpaar D., Bykin A., Dreger D. (2004) Potatoes. Minsk: Orekh NUE, 2004. 465 p. (in Russian).

6. Averkieva Ye. G. (1988) Potatoes and its culture. Moscow: Colossus, 1988. 253 p. (in Russian).

7. Rudenko H. S., Tkachuk I. A. (1980) Potato fertilizer system. Kyiv: Harvest, 1980. 48 p. (in Ukrainian).

8. Vlasenko N. Yu. (1987) Fertilization of potatoes. Moscow: Agropromizdat, 1987. 261 p. (in Russian).

9. Kuchko A. A., Mytsko V.M. (1997) Physiological bases of crop formation and potato quality. Kyiv: Trust, 1997. 126 p. (in Ukrainian).

10. Shul D. (2001) Study of the efficiency of superbiofertilizer by the Podil Research Station of the Ternopil institute of agricultural production. Ternopil, 2001. 278 p. (in Ukrainian).

11. Bondarenko H. L., Yakovenko K. I. (2001) Methodology of experimental business in vegetable growing and melons. Kharkiv: The Basis, 2001. 370 p. (in Ukrainian).

12. Moiseychenko V. F., Trifonova M. F., Zaviryukha A. Kh. (1996) Fundamentals of scientific research in agronomy. Moscow: Kolos, 1996. 336 p. (in Russian). 


\section{Аннотация}

\section{Мялковський Р. А., Безвиконный П.В., Мулярчук О.И., Кравченко В.С.}

Эффективность внекорневой подкормки микроудобрениями на биохимические показатели клубней картофеля

Приведень результаты внекорневой подкормки микроудобрениями на биохимические показатели клубней картофеля в условиях Правобережной Лесостепи Украины. Установлено, что применение внекорневых подкормок микроудобрениями Реаком, Кристалон особый и Розасоль приводило к повышению содержания сухого вещества, крахмала и витамина С. По результатам химического анализа установлено, что в среднем за три года самым высоким содержанием сухого вещества отличались варианты с внесением микроудобрений Реаком в норме 4,50 кг/га сорта Алладин - 24,55\%, Дар - 24,34\%. Анализ содержания сухого вещества в клубнях с обработкой растений Кристалоном особенным высокими показателями выделяется норма внесения 2,50 кг/га, у сорта Алладин-24,14\%, Дар - 24,18\%, что по сравнению с контрольным вариантом было выме на 0,71\% и 0,84\% соответственно. С применением внекорневой подкормки микроудобрения Розасоль наибольшим содержанием сухого вещества в клубнях характеризовался вариант с нормой внесения 2,50 кг/га сорта Алладин - 24,06\%, Дар - 24,06\%. Высоким содержанием крахмала характеризовался вариант с внекорневой подкормкой микроудобрением Реаком. Так, сорта Алладин в среднем за годы исследований высокий показатель отмечено от обработки растений с нормой микроудобрений 4,50 кг/га, где содержание крахмала составил 21,7\%, тогда как на контрольном варианте только 20,3\%. Аналогичные показатели и сорта Дар, (среднее за три года) - 17,5\%, на контроле - 16,3\%. В целом применения микроудобрений при внекорневой подкормки растений картофеля превышали по содержанию витамина С контрольный исследуемый вариант.

Ключевые слова: картофель, сорт, микроудобрения, внекорневые подкормки, урожай, сухое вещуество, крахмал, витамин $C$.

\section{Annotation}

\section{Myalkovsky R., Bezvikonnyi P., Mulyarchuk O., Kravchenko V.}

Efficacy of foliar application of microfertilizers on the biochemical parameters of potato tubers

The results of the foliar application of micronutrients on biochemical parameters of potato tubers in the conditions of the Right Bank Forest-steppe of Ukraine. It has been established that application of micronutrient fertilizers Reakom, Crystalone special and Rozasol led to an increase in the content of dry matter, starch and vitamin C. According to the results of the chemical analysis, it was found that the highest content of dry matter was noted with variants containing microfertilizers with Reakom with a norm of $4.50 \mathrm{~kg} / \mathrm{ha}$ on average for three years, the variety of Alladin - 24.55\%, Dar-24.34\%. Analysis of dry matter content in plants treated with Crystalone special is characterized by the highest rates $2.50 \mathrm{~kg} / \mathrm{ha}$, in the 
Alladin variety $-24.14 \%$, Dar $-24.18 \%$, in comparison with the control variant, they were higher by $0.71 \%$ and $0.84 \%$, respectively. With the use of foliar fertilization of microfertilizer, Rozasol, the highest content of dry matter in the tubers was characterized by a variant with an application rate of $2.50 \mathrm{~kg} / \mathrm{ha}$ of Alladin grade $-24.06 \%$, Dar-24.06\%. The highest content of starch was characterized by the variant with foliar fertilization by microfertilizer Reakom. Thus, Alladin variety, on average, over the years of research, the highest was recorded from the treatment of plants with the norm of microfertilizers of $4.50 \mathrm{~kg} / \mathrm{ha}$, where the content of starch was $21.7 \%$, whereas in the control variant it was only $20.3 \%$. Dar variety has similar indices, (average for three years) $-17.5 \%$, in control - 16.3\%. In general, microfertilizers used in foliar fertilization of potato plants were higher than the control vitamin $C$ content.

Key words: potato, variet, microfertilizer, foliar fertilization, crop, dry matter, starch, vitamin $C$.

\title{
ВПЛИВ БІОПРЕПАРАТУ ПОЛІМІКСОБАКТЕРИН ТА IМУНОПРОТЕКТОРА ВАI-SI НА ВМІСТ ФОТОСИНТЕТИЧНИХ ПІГМЕНТІВ І УРОЖАЙНІСТЬ КУКУРУДЗИ
}

\author{
В. М. ГАВІЙ, кандидат біологічних наук \\ О. Б. КУЧМЕНКО, доктор біологічних наук \\ О. О. ТЕРЕЩЕНКО \\ Ніжинський державний університет імені Миколи Гоголя
}

У статті наведена порівняльна характеристика впливу біопрепарату Полімікосбактерин та імунопротектора BAI-SI на вміст зелених фотосинтетичних пігментів у листках рослин кукурудзи на основних фазах онтогенезу $i$ iï урожайність. Встановлено, що зазначені препарати ефективно збільшили вміст хлорофілів у листках рослин кукурудзи та ї урожайність.

Ключові слова: біопрепарат, імунопротектор, фотосинтетичні пігменти, вміст хлорофілів, урожайність.

Постановка проблеми. Кукурудза $\epsilon$ однією 3 основних зернових культур як в Україні, так i y всьому світі. Проблеми підвищення продуктивності рослин кукурудзи вирішуються не лише селекційногенетичними методами, а й застосуванням біопрепаратів та синтетичних 